\title{
The Effects of Socio-Cultural Variables on the Application of Ethical Standards for Turkish Accountants
}

Ali Kartal, Mehmet Sinan Bozok *

Abstract:

Ethical standards are needed for all professional organizations and associations. One of the most important ethical standard applications that belong to the accountants can be given as example for these applications. At the same time, it is also the case that the application of these standards will be affected according to the sociocultural values of the society concerned. Therefore we should examine the effect of social-cultural values on accountants' behavior in each society separately.

If we know the influence of these variables on the behavior of the individuals concerned, we can establish special additional rules and regulations for that specific society. In this way, the negative effects of the application of ethical standards on ethical behavior in each specific society can be eliminated.

For this reason, this paper will provide information on ethical standards for accountants and explore the possible influence of socio-cultural values on accountants in connection with Hofstede's research. We will then try to determine these relationships from the viewpoint of Turkish accountants through our research. Our paper will conclude with suggestions on how to enhance the code of professional conduct in Turkey.

Keywords: Ethical standards, Culture, Accountants, Hofstede's measures, Ethical behavior

JEL: M40, M41, M14

DOI: $10.2478 / v 10033-011-0001-3$

\section{Introduction}

Culture can be described as '... the interactive aggregate of common characteristics that influence a human group's response to its environment' (1). In other words, culture includes language, religion, lifestyle, custom and so on, common characteristics of a society, and these variables influence the general nature of individuals' behavior in society.

When a US businessman travels to a country in which time is not very important (for example, an undeveloped country) his agreement period probably will take much more time than normally expected (2). Japanese small retail stores can be given as another example because Japanese people prefer to buy fresh food on a daily basis within walking distance even though their lifestyle has been affected by Western styles of living (3)
Within the same vein, the application of some ethical standards which are successful in some countries may be unsuccessful in other countries. In other words, we need additional or different details when applying ethical standards in different societies. For example, the application of a standard of objectivity will be more

* Ali Kartal

Anadolu University

Faculty of Economics and Administrative Sciences

E-mail: akartal@anadolu.edu.tr

Mehmet Sinan Bozok

Anadolu University

Open Education Faculty

E-mail: sbozok@anadolu.edu.tr 
difficult in a developing country than in a developed country. Thus, a developing country will probably need more rules and additional regulations than a developed country in order to have more successful ethical standards.

As seen in the examples given above, to get the most out of the application of a professional code of conduct, the effects of social-cultural variables on accountants should be understood before decisions are made in order to minimize negative influences on their behaviors.

We will first speak a little bit about the ethical standards for accountants, then briefly examine the possible influences of the socio-cultural variables on applications of ethical standards in Turkey. Later we will analyze the results of computer output that will show us expected problem areas during the applications of ethical standards in Turkey. The paper concludes with suggestions for enhancing the professional code of conduct in Turkey

\section{Ethical Standards}

Both external and internal accountants are expected to obey ethical standards. An unethical act is one that violates the ethical standards of the profession. Recent accounting scandals, such as Enron, for example, and the latest world economic crisis, have especially shown us the importance of ethical standards.

To overcome these kinds of ethical problems, the Institute of Management Accountants (IMA) has developed ethical standards to help management accountants. There is also a Code of Professional Conduct that was established by AICPA for its members, and the Main Ethics Principles, which were established by the IFAC. All of them have the same purpose of establishing ethical standards for accountants.

In Turkey, ethical standards for accountants were established in 1987 with Capital Market Law regulations and other regulations, as well as the additional ethical Principles and Rules issued in 1990 and 1996. Two main special regulations for ethical standards in Turkey were made by TÜRMOB in 2001 and 2007. These studies also address the same subjects as the IMA, AICPA and IFAC regulations.

Since standards leave much room for individual interpretation and judgments, many ethical dilemmas require value judgments and not the simple application of standards. In other words, ethical standards are the same for all over the world, but their applications are affected by the social-cultural values of each country. In this study we will try to explain this subject by using the classifications of IMA for ethical standards during our analysis.

First, we can explain these standards in the summary below as Competence, Confidentiality, Integrity and Objectivity. (4) Competence: Maintain professional competence in knowledge and skills. Perform professional duties according to the relevant laws, regulations, and technical standards. Confidentiality: Refrain from the disclosure of information learned about customers' businesses except when authorized or legally obligated. Integrity: Refuse any gift, favor, hospitality or any other benefit that would influence your actions. Objectivity: Communicate information fairly and objectively.

\section{Socio-cultural Changes in Turkish Society}

Turkish society is in the process of rapid change, as has been seen in almost all of the societies in the world. This change started with the foundation of the Republic Of Turkey in 1923 and it continued with the effect of revolutions (in the alphabet, government management, education, clothes, industrialization, etc.)

During the Ottoman Empire, Turkish people lived in a lineal orientation in which the members of the families took care of ancestral graves, obeying the wishes of members long since dead, and tending to their elderly parents. Furthermore, children were expected to continue this tradition.

Part of this foundation arose from the Ottoman Empire's administrative system under which wide and very old extended families ran the Empire. This value system is similar to Chinese and Japanese value systems (5). At that time, the decision maker was generally the father, with the family members being expected to entirely obey (6). Sons and grandsons remained in the family until the father's death, when the eldest son took over and the younger sons set up an independent household (7).

With the establishment of the Republic of Turkey in 1923, a collateral structure started to take the place of the lineal family orientation. In fact, kinship (collateral) relationships have become the most important aspect in society, in part due to a diminished sense of historical consciousness arising from the establishment of the Republic of Turkey. 
In this structure, extended family members spend their leisure time together, cooperate in work, and help each other in economic crises or the arrival of an unexpected guest. Due to changes in the socio-political structure, the old family names, which derived from occupations, are not used any more. Sometimes, women and children do not even know their own official surnames, and only those responsible for official village business will know all the village surnames (8).

During the first years of the Republic of Turkey, Turkish people neither had much experience in business nor enough capital to open businesses because they worked in the different management or army levels of the Ottoman Empire. Thus the Turkish government established many state owned companies in Turkey. In these companies, Turkish people learned how to do business and found opportunities to increase their incomes.

Greater industrialization was seen especially in 1950. With this industrialization the population migrated from rural to urban areas, thus creating a nuclear family structure, with parents and children living together until marriage.

Today, the private sector has developed very strong power over the Turkish economy. Thus, the government started to sell some of the government companies to the private sector because of the increasing business experience of the private sector in Turkey. Revolutions, industrializations, and increases in education level have decreased the effect of collateral orientation and authority - a centered orientation in society. Consequently, nowadays, especially in the developed parts of Turkey, people are seen in a democratic and individualistic orientation in which families are childcentered, and people are seen as mobile, active, independent, open, and with direct specialties.

As a result of these developments, Turkish people have changed their lifestyles and socio-cultural values to accord more with Western lifestyles. Although this kind of change is pushing their demand for products of worldwide standards, the influence of these socio-cultural values on Turkish accountants should also be checked before making decisions about them. Accountants of every country may have some special and different perceptions about ethical behavior even though they have a Western lifestyle.

\section{The Relationship between Social-cultural Variables and Ethical Standards}

Since the differences of cultural variables affect a person's behavior, there are many studies on this subject. One of the most important studies on this subject was made by Geert Hofstede. From 1967 to 1973, Hofstede used data from 116,000 IBM employees from more than 50 countries and established four main dimensions that have given us an opportunity to know how to differentiate between cultures. These dimensions are power distance, individualism/collectivism, Masculine/feminine, and uncertainty avoidance. By using the values of these dimensions of a certain country, it is possible to have an idea about the behavior of that country's people. Later Hofstede added a fifth dimension, Confucian dynamism, to his theoretical framework with Michael $\mathrm{H}$. Bond. The values of these cultural dimensions, which are issued for each country separately by Geert Hofstede, have been intensively used in many crosscultural studies in the world.

According to Hofstede's measures of national culture, Turkey is seen in terms of the dimensions of power distance and uncertainty avoidance as having a significant power distance and uncertainty avoidance, and from the view point of the dimensions of individualism and masculinity as collectivist and feminine (9). Therefore the following connections with social-cultural variables and ethical standards for Turkey can be made using the following information (10): (see Table 1)

\begin{tabular}{|l|c|c|c|}
\hline & Turkey & $\begin{array}{c}\text { Difference } \\
\text { in Index }\end{array}$ & USA \\
\hline $\begin{array}{l}\text { Individualism } \\
\text { (IDV) }\end{array}$ & 37 & $(54)$ & 91 \\
\hline $\begin{array}{l}\text { Uncertainty } \\
\text { Avoidance Index } \\
\text { (UAI) }\end{array}$ & 85 & $(39)$ & 46 \\
\hline $\begin{array}{l}\text { Power Distance } \\
\text { Index (PDI) }\end{array}$ & 66 & $(26)$ & 40 \\
\hline Masculinity (MAS) & 45 & $(17)$ & 62 \\
\hline
\end{tabular}

\section{Table 1}

The individualism aspect (IDV) ranks first with a 54 point change in index values between the USA and Turkey. This dimension of culture is very important for the accounting profession because individualism means independence and objectivity, in other words freedom 
from the influence of others. One of the most important indicators for individualism is the nature of the family, and the structure of the Turkish family has been changing from an extended family to a nuclear family structure. According to the index value it is not enough to speak about the situation of individualism in Turkish society. Most likely this will affect objectivity standard applications negatively for an accountant.

Uncertainty Avoidance Index (UAI) ranks second with a 39 point difference in index values between the USA and Turkey. The high value in this dimension indicates low tolerance in that country and it can be said that the country is a rule oriented society. Thus, we can say that Turkish accountants need more rules than USA accountants according to the results of the UAI index for the two countries. This dimension can be concerned with competence standards, and other related regulations and rules.

Power Distance Index (PDI) ranks third with a 26 point difference in index values for these two countries. According to Hofstede, the power distance index is a measure of the interpersonal power of influence between $B$ (boss) and $\mathrm{S}$ (subordinate) as perceived by the less powerful of the two. Therefore, in high power distance countries, a local auditor may meet more difficulty resisting pressures from powerful and wealthy customers (11). In other words, a high power distance figure indicates inequality of power and wealth between accountant and customer (boss). This situation will affect the behavior of accountants from the view point of competence and objectivity standards.

Masculinity (MAS) ranks last with a 17 point difference in index values between the USA and Turkey. A high value for this index shows us a high degree of gender differentiation. In this kind of culture, males dominate a significant position in society. According to Hofstede's MAS index, the Turkish value is forty-five, whereas that of the USA was sixty-two; hence Turkish society has a lower level of differentiation. Thus it can be said that females are treated more as the equals of males than in the USA.

Since gender differences may affect ethical perceptions, during research on ethical issues the influence of this situation should not be forgotten. For example, a study has shown that women are significantly less tolerant of unethical behavior that promotes their self interest than men are (12). This would be more of a positive aspect for the application of ethical standards in Turkey than in the USA. Because work is not central to life in a feminine based society, quality of life, time off, and vacations might be more important than financial rewards to the Turkish accountants, and more effective motivators (13).

Short-Term/Long Term Orientation (Confucian Dynamism). The main characteristics of long-term oriented societies are persistence, using status to order relationships, thrift, and having a sense of shame, which are considered marks of personal steadiness and stability, as well as protecting one's face and respect for tradition, while reciprocating greetings, favors, and gifts are all characteristic of short-term oriented societies (14). While Hong Kong, South Korea and Taiwan are seen as longterm oriented countries, the USA is seen as a short-term oriented country. This dimension of culture can be connected with competence and integrity standards of ethics. In other words, a lack of persistence, using status to order relationships, thrift, and having a sense of shame in short-term oriented cultures can affect negatively the application of competence and integrity standards of ethics. And while financial rewards may be important in short-term oriented societies, status, job title, job satisfaction, and education opportunities may be more important in long-term oriented societies.

\section{Research and Explanation of Results}

Five main questions, each of which concerned a different cultural aspect of Hofstede's measures, were posed to 100 accountants in Turkey. These accountants were selected at random from all over Turkey. Using the answers given by the accountants five hypotheses will be established and according to the results of these hypotheses the expected ethical behaviors of Turkish accountants will be determined and compared with Hofsdete' $s$ findings from the perspective of ethical behavior. At the same time these collected data will also be subjected to principal component analysis and the results will be connected with a chi-square analysis and Hofstede's findings. This study will show us the needed modification areas during the applications of ethical standards in Turkey and the paper will conclude with suggestions for enhancing the rules of the code of professional conduct in Turkey. The same approach could also be applied to any country to get the highest application of ethical rules. 


\begin{tabular}{|l|c|c|c|c|c|}
\hline & Individualism & Uncertainty & P. Distance & Masculinity & C.Dynamism \\
\hline Chi-Square * & 39,000 & 76,100 & 22,300 & 72,600 & 32,200 \\
\hline df & 4 & 4 & 4 & 4 & .000 \\
\hline Asymp.Sig. & .000 & .000 & .000 & & .000 \\
\hline & & & & & \\
\hline
\end{tabular}

*. 0 cells $(, 0 \%)$ have expected frequencies less than 5 .The minimum expected cell frequency is 20.0.

Table 2: Test Statistics

\begin{tabular}{|l|c|c|c|c|c|c|}
\hline & \multicolumn{3}{|c|}{ Extraction Sums of Squared Loadings } & \multicolumn{3}{c|}{ Rotation Sums of Squared Loadings } \\
\hline Component & Total & $\%$ of Variance & Cumulative \% & Total & $\%$ of Variance & Cumulative \% \\
\hline $\mathbf{1}$ & 1,716 & 34,316 & 34,316 & 1,709 & 34,188 & 34,188 \\
\hline $\mathbf{2}$ & 1,016 & 20,317 & 54,633 & 1,022 & 20,445 & 54,633 \\
\hline
\end{tabular}

Extraction Method: Principal Component Analysis.

Table 3: Total Variance Explained

\begin{tabular}{|l|c|c|}
\hline & \multicolumn{2}{|c|}{ Component } \\
\hline & $\mathbf{1}$ & $\mathbf{2}$ \\
\hline Individualism & .758 & -.153 \\
\hline Uncertainty & -.555 & .067 \\
\hline P. Distance & .777 & .147 \\
\hline Masculinity & -.030 & .986 \\
\hline C. Dynamism & .471 & .003 \\
\hline
\end{tabular}

Extraction Method: Principal Compon. Analysis Rotation: Varimax with Kaiser Normalization

Table 4: Rotated Component Matrix

\section{Hypotheses}

H1: All of the information seen in the prepared financial statements and reports are presented objectively and fairly without being affected by anything else during my work.

H2: I need more detailed and relevant professional laws, regulations, technical standards and rules.

H3: I don't experience any overpowering influence from my customers during my work.

H4: Work is central in my life, thus my vacations are delayed sometimes

H5.Non-financial rewards are more important than financial rewards in my life

\section{Statistical Results (see in Table 2)}

\section{Explanation of Test Results}

According to the first accepted hypothesis, all of the information that is seen in the prepared financial statements and reports are presented objectively and fairly without being affected by anything else during the
Turkish accountants' work. In other words, Turkish accountants don't have any independent problems according to the individualistic aspect of Turkish culture. But this result does not coincide with the indicators of Hofstede's measures for Turkey. Our analysis determined that this aspect of culture would not affect the behavior of Turkish accountants negatively with regard to their application of objectivity standards.

According to the second accepted hypothesis, Turkish accountants need more detailed and relevant professional laws, regulations, technical standards and rules. This result was the same with the indicator of Hofstede's measures for Turkey. In other words, Turkish accountants do need more rules than US accountants according to the uncertainty avoidance aspect of their culture. Turkey also is characterized as a kind of ruleoriented society and country. On competence Standard, it should be worked more than US.

According to the third accepted hypothesis, Turkish accountants do not have any overpowering influence from their customers during their work. This result does not coincide with the indicator of Hofsetde's measures for Turkey. Our analysis determined that this aspect of culture would not affect the behavior of Turkish 
accountants negatively with regard to their competence and application of objectivity standards...

According to the fourth accepted hypothesis, work is central in a Turkish accountant's life. This result does not coincide with the indicator of Hofsetde's measures for Turkey. In other words, Turkish society is not characterized as a feminine society. Even though it is seen as having a lower level degree of gender differentiation in Hofstede's research on Turkey, according to the accepted hypothesis Turkish accountants have a high degree of gender differentiation. Therefore, we can say that Turkish accountants are significantly more tolerant of unethical behavior. This aspect of the culture can have a negative effect on ethical perceptions and may raise problems in the application of competence and objectivity standards in Turkey.

According to the last accepted hypothesis, nonfinancial rewards are more important than financial rewards in the lives of Turkish accountants. We say that Turkish society can be considered a long-term oriented society, where status, job title, job satisfaction and education opportunities may be more important. This aspect of its culture should not be forgotten during the application of ethical standards in Turkey.

When these collected data was also subjected to principal component analysis, the total variance explained was taken from an SSPS application with two components. As can be seen in table 3 , the cumulative percent of variance for components 1 and 2 is $54.63 \%$. In other words, the explanation of the percent of variance of these 2 components is 54.63. At the end of the analysis the rotated component matrix is seen in table 4 is

According to the factor analysis of the results in table 4, the first component shows us the characteristics of Turkish accountants, who do not have any independent problems, need more rules, have equality, and want nonfinancial rewards, while the second component shows us that work is central for Turkish accountants from the viewpoint of Hofstede's measurements. These results are also in agreement with the results of a chi-square analysis of our study.

\section{Conclusion}

After analyzing all of the data given above, the following results and suggestions could be summarized for enhancing the rules of the code of professional conduct in Turkey.

\begin{tabular}{|l|c|c|}
\hline \multicolumn{1}{|c|}{$\begin{array}{c}\text { Hofstede's } \\
\text { measures of } \\
\text { behavior }\end{array}$} & $\begin{array}{c}\text { Accepted } \\
\text { Hypothesis }\end{array}$ & Effect on ethical \\
\hline Individualism & $\begin{array}{c}\text { Don't have } \\
\text { Independence } \\
\text { problem }\end{array}$ & Objectivity \\
\hline $\begin{array}{l}\text { Uncertainty } \\
\text { Avoidance }\end{array}$ & Need more rules & Competence \\
\hline Power distance & Work is central & $\begin{array}{c}\text { Objectivity / } \\
\text { Competence }\end{array}$ \\
\hline Masculinity & Non-financial behavior \\
\hline reward & $\begin{array}{r}\text { Competence and } \\
\text { Integrity }\end{array}$ \\
\hline
\end{tabular}

As a result, Turkish accountants do not have any independent problems, need additional regulations and rules to decrease uncertainty and to reduce the degree of tolerance of unethical behavior, and the need to establish non-financial rewards systems rather than financial systems to increase the success of ethical applications in Turkey. On the other hand, this kind of approach can be used for all societies making modifications to their ethical standards before their application in order to get the best results. [

\section{References}

CHESANOW, Neil. 1985. The World-Class Executive How to do Business Like a Pro Around the World, New York, p.273.

Geert HOFSTEDE. 1980. Culture's Consequences: International Differences in Work-Related Values, Beverly Hills, California: Sage Publications, p.19.

Steven GLOBERMAN. 1986. Fundamentals of International Business Management, Englewood Cliffs, New Jersey: Prentice-Hall, p.144.

Charles T.Horngren, Gary L.Sundem, William O.Stratton. 1996. Introduction Management Accounting, Tenth edition, Upper Saddle River,NJ:Prentice-Hall International, Inc., p.23.

John C.CONDON \& Fathi YOUSEF. 1975. An Introduction to Intercultural Communication, New York, N.Y, Macmillan Publishing Co., pp.74-75.

Paul STIRLING, Turkish Village. 1965. New York, N.Y.:John Wiley \& Sons, Inc. p.149.

\section{CONDON \& YOUSEF, p.76.}

STIRLING, p.148.

Geert HOFSTEDE. 1985. 'The Interaction between National and Organizational Value Systems,' Journal of Management Studies, p.351 and 354.

www.geert-hofstede.com/hofstede -turkey.shtml

COHEN, Jeffrey R., PANT Laurie W., SHARP David J. 1993. 'Culture based ethical conflicts confronting multinational accounting firms, Accounting Horizons; (Sarasota; p.7.

C, John, Portz, Kris. 2003. 'Management Control Systems in a Global Economy', The CPA Journal; p.3. 